\title{
PERFORMERS' RIGHTS AND COPYRIGHT: THE PROTECTION OF SOUND RECORDINGS FROM MODERN PIRATES
}

Recently, the recording industry has run full page ads in trade publications which read: "WARNING: . . . The unauthorized duplication of tapes and records is plain theft." 1 What these ads are not able to assert is that this "theft" is illegal. The law in regard to the unauthorized duplication of sound recordings ${ }^{2}$ is far too uncertain to make such a declaration possible.

Copyright protection for sound recordings would be permissible under the copyright clause of the Constitution which provides that Congress may secure to authors for limited times the exclusive right to their "Writings." For while a sound recording may not appear to be a writing within the common meaning of that word, the Supreine Court has construed "writings" so broadly that it must now be read to include recorded performances." Recordings are the tangible expression of the musical artist's intellectual creation, just as the written word is the tangible expression of the author.

1. NewsweEk, Oct. 5, 1970, at 70 .

2. The term sound recordings as used in this Comment refers to any work that results from the fixation of a series of musical, spoken, or other sounds, regardless of the material objects, such as phonograph records or tapes, in which they are embodied.

3. U.S. CoNST. art. I, \& 8: "The Congress shall have Power . . . To promote the Progress of Science and useful Arts, by securing for limited Times to Authors and Inventors the exclusive Right to their respective Writings and Discoveries." See, e.g., Capitol Records, Inc. v. Mercury Records Corp., 221 F.2d 657, 660 (2d Cir. 1955); Chafee, Reflections on the Law of Copyright, 45 Colum. L. Rev. 719, 735 (1945); Kaplan, Performer's Right and Copyright, 69 HARv. L. REv. 409, $413-14$ (1956); Nimmer, Copyright Publication, 56 ColUM. L. Rev. 185, 190 (1956).

Abraham Kaminstein, Register of Copyrights, has stated:

[T] here is no doubt in my mind that recorded performances represent the 'writings of an author' in the Constitutional sense and are fully as creative and worthy of copyright protection as translations, arrangements, or any other class of derivative works. I also believe that the contributions of the record producer to a great many sound recordings also represent true 'authorship' and are just as entitled to protection as motion pictures and photographs. No one should be misled by the fact that in these cases the author expresses himself through sounds rather than words, pictures, or movements of the body . . . .

Hearings on H.R. 4347, H.R. 5680, H.R. 6831 and H.R. 6835 before Subcomm. No. 3 of the House Comm. on the Judiciary, 89th Cong., 1st Sess. ser. 8, pt, 3, at 1863 (1965) [hereinafter cited as 1965 Hearings].

4. See Mazer v. Stein, 347 U.S. 201 (1954) (statuettes used as bases for electric lamps); Bleistein v. Donaldson Lithographing Co., 188 U.S. 239 (1903) (chroinolithograph picture on circuit show bills); Burrow Giles Lithographic Co. v. Sarony, 111 U.S. 
Congress, however, did not include protection for sound recordings in the present Copyright Act. ${ }^{5}$ Such protection was proposed during the 1909 revision of the statute, but was explicitly rejected ${ }^{8}$ in favor of a compulsory license. ${ }^{7}$ Thus, performers and record manufacturers $^{8}$ have been left with no federal statutory protection for their works. ${ }^{9}$

Traditionally, however, courts have often been able to grant recovery to performers for the unauthorized duplication, ${ }^{10}$ and even the

53 (1883) (photographs). But cf. Mazer v. Stein, supra at 219-21 (Douglas, J., dissenting).

5. 17 U.S.C. $\$ \S 1$ et seq. (1964); see Capitol Records, Inc. v. Mercury Records Corp., 221 F.2d 657, 661 (2d Cir. 1955); M. NIMMER, NIMMER ON COPYRIGHT $\$ 35$, at 143.4 (1970); StafF of Subcomm. on Patents, Trademarks, and Copyrights of the Senate Comm. on the Judiciary, 86th Cong., 2d Sess., Copyright LaW Revision Studies 7 (Comm. Print No. 26 (1961) thereinafter cited as Senate Studies]; Chafee, supra note 3 , at 735-36.

The Copyright Office will not accept a phonograph record to register either the coinposition recorded on it or any "claims to exclusive rights in mechanical recordings themselves, or in the performances they reproduce." 37 C.F.R. $\$ 202.8(b)$ (1971).

6. The report of the Committee on Patents issued preliminarily to the adoption of the Act stated:

It is not the intention of the Committee to extend the right of copyright to mechanical reproductions themselves, but only to give the composer or copyright proprietor the control, in accordance with the provisions of the bill, of the manufacture and use of such devices.

H.R. REP. No. 2222, 60th Cong., 2d Sess. 9 (1909).

The court, in Capitol Records, Inc. v. Mercury Records Corp., 221 F.2d 657 (2d Cir. 1955), relied on this passage and another from the same report in concluding that phonograph records are not copyrightable writings under section 4 of the Act. See M. NIMMer, supra note 5, at $\S 12.2$. But cf. Fonotipia Ltd. v. Bradley, 171 F. 951 (E.D.N.Y. 1909) (stating in dictum that phonograph records would be copyrightable under the Act which had been enacted but was not yet in effect at that time).

7. 17 U.S.C. $\S \S 1(\mathrm{e}), 101(\mathrm{e})$ (1964). Under the compulsory license the composer or copyright proprietor of a musical work has the exclusive right to license the first recording of the work. Once it has been recorded by this original licensee, the work may be recorded by anyone so long as the statutory royalty fee of two cents is paid to the copyright owner for each copy made.

8. For the purposes of this Comment the rights of record manufacturers are treated the same as those of the recording artists. While it may be true that in some cases the manufacturer will contribute little to the recording of a performance, in most cases his contribution, in terms of sound quality and arranging, are quite significant. The manufacturer's interest in the sound recording, artistically and financially, is thus within the scope of the arguments advanced here.

9. Phonograph records are provided with one form of protection by 18 U.S.C. \$ 2318 (1964), which provides criminal penalties for the interstate transportation, or the knowing sale of phonograph records transported in interstate commerce which bear forged or counterfeited labels. This statute in no way affects the sale of duplicated recordings sold under the duplicator's own label.

10. "Duplication," when used in this Comment, refers only to the practice of reproducing or re-recording the actual sounds of a recording by any means for sale to the public. This practice is known as "piracy" or "dubbing." Imitation of a performer's work, no matter how minute and unethical, is generally permissible and raises issues not within the scope of this Comment. 
unlicensed broadcasting of their sound recordings under various common law theories. The two most common of these have been common law copyright ${ }^{11}$ and the doctrine of unfair competition. ${ }^{12}$ However, two recent decisions of the Supreme Court, Sears, Roebuck \& Co. v. Stiffel Co ${ }^{13}$ and Compco Corp. v. Day-Brite Lighting, Inc., ${ }^{14}$ cast some doubt on the continued validity of this practice.

The purpose of this Comment is to review briefly the development of the law in this area, to determine what protections are now available to recording artists and record manufacturers, and to analyze the protection which will be accorded them under the proposed Copyright Revision Bill which was before the Senate Judiciary Committee during the last term of Congress. ${ }^{15}$

\section{I}

\section{Common LaW Protection of Sound Recordings}

\section{A. Unfair Competition Protection}

Protection of sound recordings against a form of unauthorized duplication began early in this century based upon the theory of unfair competition. ${ }^{16}$ In Victor Talking Machine Co. v. Armstrong ${ }^{17}$ the plaintiff had been successfully recording and selling disks containing the performances of famous musical artists. The defendants purchased some of these disks and used them to produce exact duplicates which were represented to the public as those of the plaintiff. ${ }^{18}$ The court had no difficulty in finding the three traditional elements of a cause of action for unfair competition. ${ }^{19}$ First, there was competition: both parties were selling the same recordings. Second, there was appropriation of a business asset in the form of the recordings themselves. And third, there was "passing off" because the defendant was representing his records as those of the plaintiff, causing confusion among purchasers as to

11. See, e.g., Capitol Records, Inc. v. Mercury Records Corp., 221 F.2d 657 (2d Cir. 1955); Waring v. WDAS Broadcasting Station, Inc., 327 Pa. 433, 194 A. 631 (1937).

12. See, e.g., Waring v. WDAS Broadcasting Station, Inc., 327 Pa. 433, 194 A. 631 (1937); Metropolitan Opera Ass'n v. Wagner-Nicliols Recorder Corp., 199 Misc. 786, 101 N.Y.S.2d 483 (Sup. Ct. 1950), aff'd, 279 App. Div. 632, 107 N.Y.S.2d 795 (1951).

13. 376 U.S. 225 (1964).

14. 376 U.S. 234 (1964).

15. S. 543, 91 st Cong., 1st Sess. (1969).

16. See generally Chafee, Unfair Competition, 53 HARv. L. Rev. 1289 (1940); Gamboni, Unfair Competition Protection, in 15 ASCAP CopYRIGHT LAW SYMPosium 1 (1967).

17. 132 F. 711 (S.D.N.Y. 1904).

18. Id. at 712 .

19. Senate Studies 17; see, e.g., Chafee, supra note 16. 
the source of the goods. The court issued an injunction forbidding further duplication. ${ }^{20}$

A few years later, the application of the doctrine of unfair competition to the record industry was substantially broadened. In Fonotipia Ltd. v. Bradley, ${ }^{21}$ the defendant had copied the plaintiff's recordings of virtuoso performers but lie did not pass his records off as those of the plaintiff: the advertising clearly disclosed that his recordings were not originals. The court, however, held that the passing off element was no longer necessary to a cause of action for unfair competition, and that equitable relief slould be granted wherever one party gains a commercial advantage by appropriating the salable properties of another's product or idea. ${ }^{22}$ Bradley has been sharply criticized for its dictum that phonograph records would be copyrightable under the $1909 \mathrm{act}^{23}$ and has been partially overruled on other grounds. ${ }^{24}$ Nevertheless, it was a prelude to the famous case of International News Service v. Associated Press, ${ }^{25}$ and was relied on as authority in several later performers' rights decisions. ${ }^{26}$

In International News Service, the Supreme Court opened the door for courts seeking to use the doctrine of unfair competition to protect performers, and other authors not within the Copyright Act, from all manner of misappropriations of their works. Both parties were international news services engaged in the business of gathering and selling news to subscribers. The Associated Press was the larger of the

20. $132 \mathrm{~F}$. at 712 .

21. 171 F. 951 (E.D.N.Y. 1909).

22. "[W]here the commercial value of the imitation hes in the fact that it takes advantage of and appropriates to itself the ... salable properties of the original, equity should grant rehef." Id. at 964 .

23. See, e.g., Senate Studies 5, 18.

24. In G. Ricordi \& Co. v. Haendler, 194 F.2d 914 (2d Cir. 1954), the court stated: "So far as [Bradley] may be thought to conflict with what we are holding, it is overruled." Id. at 916. In Ricordi the defendant had reproduced and sold the plaintiff's printed edition of a no-longer-copyrighted opera by means of a photographic process. The plaintiff claimed that this was unfair competition under New York law but the conrt disagreed. Judge Hand reasoned for the majority that state protectiou for the typography was foreclosed because the original book, "appearing as it did with an unlimited copyright notice, would give notice to the public of a claim to the protection of the Copyright Act over all that appeared in it; and that would imply that, when the copyright expired, the 'work' in all its aspects would be in the public demesne." Id. at 915. In short, the court found that the plaintiff had not reserved any protection for its work beyond that afforded by the Copyright Act. It did not decide whether a notice reserving the publisher's right in the typography would have served this purpose.

The court also stated that a defendant might be guilty of unfair competition in such a case, but that such a holding would require some conduct of the defendant other than copying. Id. at 916.

25. 248. U.S. 215 (1918).

26. See, e.g., cases cited note 12 supra. 
two and apparently had a faster news gathering and intelligence network. International News Service copied news releases from Associated Press' bulletin boards and early edition newspapers and sold them to its own customers. While there was some question as to whether news could constitute a business asset, the Court found that there was a "quasiproperty" right in Associated Press' news releases, ${ }^{27}$ and that International News Service's copying was an illegal "misappropriation."28

In finding that the practice of International News Service constituted a misappropriation of property the Court eliminated the traditional element of "passing off" in an unfair competition suit as long as the plaintiff could show piracy of his product or labors to the competitive advantage of another. Rather than selling its own goods as those of the plaintiff, International News Service had been selling the product of the Associated Press as its own. This rule added a concern over unjust enrichment to the law of unfair competition. The new elements of a cause of action for unfair competition were the existence of a quasi-property or property right expropriated by the defendant, competition, and commercial damage.

The potential application of this rule in performers' rights cases is obvious. The performance of a musical artist recorded on a phonograph record would constitute the quasi-property right, ${ }^{20}$ competition between the artists and legitimate record manufacturers and the duplicators for record sales is apparent, and damage to the forner could be the only result.

The new rule was first applied to uphold the right of a performer to prevent the unlicensed broadcasting of his recorded perforinances. ${ }^{30}$

27. 248 U.S. at 236.

28. Id. at 242 .

29. In this respect it would be treated like the news releases in International News Service.

30. The unfair competition ground was an alternative basis for the court's decision. Primary reliance was placed on the theory that the plaintiff had a valuable property right in his recordings which was protectible under common law copyright until published. Waring v. WDAS Broadcasting Station, Inc., $327 \mathrm{~Pa} .433,441,194$ A. 631, 635 (1937). The court found the restraint stated on the labels valid, and held that it made the publication by sale of the records limited so as not to divest Waring's common law rights. Id. at 443-48, 194 A. at 636-38.

Waring also recovered on the same theory in the federal district court for North Carolina, although there appears to have been no sale of recordings in that state prior to the action. Waring v. Dunlea, 26 F. Supp. 338 (E.D.N.C. 1939).

The Waring decisions resulted in enactment in three states of statutes denying a musical performer or record producer any common law rights in recordings once copies are sold in commerce for use within the state. FLA. STAT. ANN. \$\$543.02, 543.03 (1962); N.C. Gen. Stat. \& 66-28 (1965); S.C. Code AnN. \& 66-101 (1962). See Senate Studies 9; Helfer, Copyright Revision and the Unauthorized Duplication of Phonograph Records, 14 BULL. COPYRIGHT SOc'Y 137, 149-50 (1966). 
In Waring v. WDAS Broadcasting Station, Inc., ${ }^{31}$ Fred Waring, a famous orchestra leader, had recorded several copyrighted songs and sold the records to the public with a restriction printed upon the labels stating that they were "not licensed for radio broadcast."32 The court granted an injunction prohibiting the playing of these records over the air without Waring's permission. Misappropriation was found in that the defendant had utilized "for its own profit the musical genius and artistry of plaintiff's orchestra in commercial competition with the orchestra itself" 33 which was then performing on live radio broadcasts.

Acceptance of this rule, however, was far from uniform. In $R C A$ Manufacturing Co. v. Whiteman, ${ }^{34}$ Paul Whiteman, another popular orchestra leader of the same era, sought similar relief in New York under substantially the same factual circumstances. Holding that common law copyright afforded the plaintiff no protection ${ }^{35}$ Judge Learned Hand rejected the alternative theory of unfair competition adopted in the Waring case. He was unwilling to extend the International News Service case beyond its particular facts, and, in the absence of "palming off" or misleading the public, he could find no remedy for Whiteman in the law of unfair competition. ${ }^{36}$

While the Whiteman rule is thus more restrictive than Waring, there is clear precedent for a much more liberal application of unfair

31. 327 Pa. 433, 194 A. 631 (1937).

32. Id. at 436, $194 \mathrm{~A}$. at 633.

33. Id. at $453,194 \mathrm{~A}$. at 640 .

34. RCA Mfg. Co. v. Whiteman, 114 F.2d 86 (2d Cir.), cert. denied, 311 U.S. 712 (1940).

35. The court found that once records were sold to the general public the performance was dedicated to society and divested of common law protection. The attempted servitude was held invalid. Id. at 88 . Judge Learned Hand noted that acts sufficient to dedicate rights in works copyrightable under the Copyright Act should have the same effect in the case of works that are not copyrightable, like sound recordings. He reasoned that if this were not true it would be possible to retain a perpetual monopoly in the work in contravention of "the whole policy of the Copyright Act and of the Constitution." Id. at 89; cf. Fashion Originators Guild of America v. FTC, 114 F.2d 80 (2d Cir. 1940), aff'd, 312 U.S. 457 (1941). Judge Hand's language lere parallels the reasoning of the Supreme Court in Sears, Roebuck \& Co. v. Stiffel Co., 376 U.S. 225 (1964) and Compco Corp. v. Day-Brite Ligliting, Inc., 376 U.S. 234 (1964). See part II infra.

While it may be argued that the Whiteman case applies only to the broadcasting of a genuine record and not to unauthorized duplication [see Diamond, Sound Recordings and Copyright Revision, 53 Iowa L. REv. 839, 859 (1968)], the clear imference from the decision is that the dubbing of phonograph records could not be enjomed under the theory of common law copyright. See Senate Studies 15. Under Judge Hand's reasoning, the acts which constitute publication must be defined by a federal standard, and that standard must prevent common law protection of phonograpl records after general public sale. He felt that any injustice in such a rule must be remedied by statute, not by state-created monopolies.

36. 114 F.2d at 90 . 
coinpetition concepts. A question of performers' rights involving the Metropolitan Opera was decided by a New York state court which preferred to employ an analysis similar to that used in International News Service. In Metropolitan Opera Ass'n v. Wagner-Nichols Recorder Corp., ${ }^{37}$ the Met, along with Columbia Records and the American Broadcasting Company, which held exclusive licenses from the opera company, sued to restrain the manufacture and sale of unauthorized transcriptions of live performances broadcast over the radio. The court granted relief to all three plaintiffs, primarily on grounds of unfair competition, stating that neither "competition" nor "palming off" was a prerequisite under "[t]he modern view as to the law of unfair competition."38 All that was required was an "effort to profit from the labor, skill, expenditures, name and reputation of others."30 The court based this holding on the broad principle that "[p]roperty rights of commercial value are to be and will be protected from any form of commercial immorality, and a court of equity will penetrate and restrain every guise resorted to by the wrongdoer." 40

Thus, under Metropolitan Opera two of the three original requirements of unfair competition - passing off and competition ${ }^{4}$-are eliminated. Only the third-appropriation-is required in order to give rise to a cause of action. This protection is especially valuable to performers because appropriators have no incentive to pass the recordings off as anything but what they actually are, copies of the artist's works, and because competition between the artist himself and the unauthorized records is very difficult to prove. ${ }^{42}$ Further, under this doctrine publication is irrelevant and a work may be protected regardless of the manner or scope of its distribution, thus avoiding the problem of definition raised by Judge Hand in the Whiteman case. ${ }^{43}$ Not surprisingly,

37. 199 Misc. 786, 101 N.Y.S.2d 483 (Sup. Ct. 1950), aff'd, 279 App. Div. 632, 107 N.Y.S.2d 795 (1951).

38. 199 Misc. at 796, 101 N.Y.S.2d at 492.

39. Id.

40. Id.

41. No claim was made that the defendant was actually competing with the opera company itself in the sale of records.

42. The musical artist is not really in the business of selling records. While he earns income from the sale of his legitimate recordings, it is difficult to show competition between himself as a performer and the sale of his records to the public. It may even be argued that the sale of the duplicated records helps the performing artist by disseminating his music and increasing his popularity.

43. The court, however, did not rest solely on the doctrime of unfair competition. It also found that the Met, and the other plaintiffs througl their exclusive contracts, had a valuable property right in the performances protectible under common law copyright until published. 199 Misc. at 798, 101 N.Y.S.2d at 494. This protection was not divested by performance in the opera louse [cf. Ferris v. Frohman, 223 U.S. 424 (1912)] or by broadcast over the radio. Cf. Uproar Co. v. National Broadcasting Co., 
the unfair competition rationale has often been used in recent performers' rights cases. ${ }^{44}$

\section{B. Common Law Copyright Protection}

Courts have not been content to rely solely on the doctrine of unfair competition in their efforts to protect performers and record manufacturers from the unauthorized duphication and sale of recorded performances. The doctrine of common law copyright has also been utilized for this purpose. This doctrine grants complete protection against unauthorized use of original intellectual creations as long as the work remains "unpublished." 45

The best exainple of the use of this doctrine is in Capitol Records, Inc. v. Mercury Records Corp. ${ }^{46}$ Capitol Records and Mercury Records had identical matrices of recordings made in Europe by several artists of various public domain works. ${ }^{47}$ The original owner of the works, who had obtained all rights from the artists, transferred the exclusive American rights to Capitol; Mercury had received rights to make and sell recordings only in certain parts of Europe. ${ }^{48}$ When it was sued for selling the recordings in the United States, Mercury claimed that Capitol liad been divested of whatever common law copyright protection it had acquired when it sold the records to the general public. ${ }^{49}$

While finding that sound recordings are copyrightable under the copyright clause of the Constitution, ${ }^{50}$ the court concluded that they are not copyrightable under the present federal act. ${ }^{51}$ The court then held that, in the absence of federal statutory protection, the doctrine of Erie Railroad Co. v. Tompkins ${ }^{52}$ requires that state law determine

8 F. Supp. 358 (D. Mass. 1934), affd, 81 F.2d 373 (1st Cir.), cert. denied, 298 U.S. 670 (1936).

44. See, e.g., Tape Indus. Ass'n of America v. Younger, 316 F. Supp. 340 (S.D. Cal. 1970); Capitol Records, Inc. v. Erickson, 2 Cal. App. 3d 526, 82 Cal. Rptr. 798 (2d Dist. 1969); Greater Recording Co. v. Stambler, 144 U.S.P.Q. 547 (N.Y. Sup. C. 1965); Capitol Records, Inc. v. Greatest Records, Inc., 43 Misc. 2d 878, 252 N.Y.S.2d 553 (Sup. Ct. 1964); Flamingo Telefilm Sales, Inc. v. United Artists Corp., 141 U.S.P.Q. 461 (N.Y. Sup. Ct.), rev'd on other grounds, 22 App. Div. 2d 778, 254 N.Y.S.2d 36 (1964); Columbia Broadcasting Sys. v. Documentaries Unlimited, Inc., 42 Misc. 2d 723, 248 N.Y.S.2d 809 (Sup. Ct. 1964).

45. Senate Studies 11; see Comment, Protection of Intellectual Property, 35 ILL. L. Rev. 546 (1941).

46. 221 F.2d 657 (2d Cir. 1955).

47. Id. at 659 .

48. Id.

49. Id. at 663.

50. Id. at 660 . Judge Learned Hand in his dissent also agreed that "there should be no doubt that [the protection of phonograph recordings under a federal copyright act] is within the Copyright Clause of the Constitution." Id. at 664.

51. Id. at 660 . Again, Judge Hand agreed. Id. at 664 .

52. 304 U.S. 64 (1938). 
what acts constitute a divestive publication of an uncopyrightable literary property. ${ }^{53}$ Making a questionable extrapolation from the Metropolitan Opera case $^{54}$ the court held that, under New York law, the public sale of phonograph records does not constitute a dedication of the right to copy and sell them to the public. ${ }^{55}$

Judge Learned Hand in dissent argued strongly in favor of total federal preemption on the question of publication, and the protection of all "published writings." " Reasoning that the majority opinion would allow phonograpli records, and all other works whose "publication" is determined by state law, to enjoy a perpetual monopoly under common law copyriglit, lie concluded that allowing states to grant such protection to writings not within the federal act would:

[D]efeat the overriding purpose of the [Copyright] Clause, which was to grant only for "limited Times" the untrammelled exploitation of an author's "Writings." Either [the author] must be content with such circumscribed exploitation as does not constitute "publication," or he must eventually dedicate his "work" to the public. . . [T] [The states are not free to follow their own notions as to when an author's right shall be unlimited both in user and in duration. . . . [O]nce it is settled that a "work" is in that class [Writings], it inust follow that it is a federal question whether he has "published" the "work." 57

53. 221 F.2d at 662 .

54. See M. NIMMER, supra note $5, \S 51.2$ at 192-94; Kaplan, supra note 3 , at 425-28; Nimmer, supra note 3.

55. "[W] here the originator, or the assignee of the originator of records of performances by musical artists puts those records on public sale, his act does not constitute a dedication of the right to copy and sell the records." 221 F.2d at 663 .

The court treated its own contrary ruling in the Whiteman case as a determination of state law under the Erie doctrine, with its holding on the publication question superseded by Metropolitan Opera. Id. See Goldstein, Federal System Ordering of the Copyright Interest, 69 CoLUM. L. REv. 49, 59 (1969).

The Third Circuit has stated that Capitol Records overruled Whiteman. Ettore v. Philco Television Broadcasting Corp., 229 F.2d 481, 488 (3d Cir.), cert. denied, 351 U.S. 926 (1956). This conclusion seems unjustified since Whiteman was a broadcasting case while Capitol Records involved an unauthorized duplication. Professor Nimmer also feels Whiteman was overruled by Capitol Records, but he concludes that it may be revived by Sears, Roebuck \& Co. v. Stiffel Co., 376 U.S. 225 (1964) and Compco Corp. v. Day-Brite Lighting, Inc., 376 U.S. 234 (1964). M. NIMMER, supra note 5, $\S 35$, at 145.2.

56. For an excellent discussion regarding the theory of federal precmption in the field of copyright see Goldstein, supra note 55 .

57. 221 F.2d at 667 . Judge Hand concluded by stating:

I recognize that under the view I take the plaintiff can have only a very limited use of its records, if it liopes to keep its monopoly. That is indeed a harsh limitation, since it cannot copyright them; but I am not satisfied that the result is unjust when the alternative is a monopoly unlimited in time and im user. 
Under this view the definition of publication is a matter of federal law under the Constitution and is consequently beyond the scope of Erie. ${ }^{58}$

The loolding of the majority, that the public sale of records did not constitute a divestive publication under New York law, was firmly adopted by a New York state court the next year. ${ }^{59}$ Thus, regardless of the questionable reasoning which led to the Second Circuit's conclusion, its decision became the law of New York.

This was the state of the law of performers' rights prior to 1964 . Over a period of half a century the courts had developed methods, sometimes inadequate and by no means uniform, for protecting performers from the unauthorized duplication of their recordings. There appear to have been no cases seeking injunctions against unauthorized broadcasting since the Whiteman decision. It is fair to assume that performers had either decided that radio play of their records was good for business, had simply given up trying to prevent such a common and publicly desirable practice, ${ }^{60}$ or had conveyed their riglits to publishers. The almost total elimination of live radio and its competition with records is certainly the major factor behind this lack of litigation. ${ }^{61}$

The imauthorized duplication problem, on the other hand, has continued to plague the industry and litigation has not ceased. The performer and manufacturer had built up a respectable body of precedent to protect themselves from record piracy. With Capitol Records as authority for applying state common law rules, they had little to worry about in most states. And while the law was often inconsistent, in the absence of a new federal statute hittle more could have been expected.

\section{II}

\section{The EFfect of the Sears and Compco Decisions}

In 1964, the long-developing scheine of protection for recording artists and record manufacturers was apparently undermined by two

58. Id. See also RCA Mfg. Co. v. Whiteman, 114 F.2d 86 (2d Cir.) (Hand, J.), cert. denied, 311 U.S. 712 (1940).

59. Gieseking v. Urania Records, Inc., 155 N.Y.S.2d 171 (Sup. Ct. 1956).

60. The desirability of public broadcasting without the performer's express permission is presumably based on the public's interest in listening to the recordings of musical artists and the performer's interest in gaining publicity for himself in order to increase his popularity.

61. This does not imply that performers are not interested in the commercial broadcast of their recordings. They strongly believe that they sliould be compensated for this use of their works and their lobbying efforts led to the inclusion of a compulsory licensing system for performance riglits, similar to that presently in existence for authors and publishers, in the revision bill. S. 543, 91st Cong., 1st Sess. $\$ 114$ (1969). This issue is discussed in part III infra. 
decisions of the United States Supreme Court: Sears, Roebuck and Co. v. Stiffel $\mathrm{Co}^{62}$ and Compco Corp. v. Day-Brite Lighting, Inc. ${ }^{.3} \mathrm{Al}-$ though both were patent cases, the Court in broad dictum indicated that its opinions were meant to apply to the law of copyright as well. ${ }^{.4}$

The plaintiffs in both Sears and Compco had introduced lighting fixtures of new and successful design. The defendants had copied these ideas and were marketing "identical . . . or confusingly similar" fixtures. ${ }^{85}$ In each case the district court invalidated the plaintiff's patents but found the defendant guilty of unfair competition under Illinois law. ${ }^{\circ 6}$ Despite the fact that there was no showing of secondary meaning in Sears, ${ }^{67}$ and no evidence of passing off in either case, ${ }^{08}$ the Court of Appeals for the Seventh Circuit affirmed the lower courts' injunctions. ${ }^{\circ 0}$

The Supreme Court, in opinions written by Mr. Justice Black, reversed both cases on federal preemption grounds:

[W] hen an article is unprotected by a patent or a copyright, state law may not forbid others to copy that article. To forbid copying would interfere with the federal policy, found in Art. I, sec. 8, cl. 8, of the Constitution and in the implementing statutes, of allowing free access to copy whatever the federal patent and copyright laws leave in the public domain. ${ }^{70}$

The Court reasoned that the patent laws constitute a carefully designed system which applies uniform federal standards "to promote invention while at the same time preserving free competition."71 Therefore Congress had expressed a policy of allowing the copying of anytling not within the Act, ${ }^{72}$ and under the supremacy clause, this policy could not be subverted by contrary state rules. ${ }^{73}$

There is wide disagreement over the precise affects of Sears and Compco on state protection of sound recordings. The Court itself recognized that federal preemption in the field of copyriglit is less than in the patent field. ${ }^{74}$ While the patent laws make no provision for a state

62. 376 U.S. 225 (1964).

63. 376 U.S. 234 (1964).

64. See 376 U.S. at 237.

65. 376 U.S. at 226.

66. Id.; 376 U.S. at 235.

67. The evidence of secondary meaning in Compco was so slight that it was probably considered only for the sake of argument.

68. See 376 U.S. at 227-28; 376 U.S. at 235.

69. Stiffel Co. v. Sears, Roebuck \& Co., 313 F.2d 115 (7th Cir. 1963); DayBrite Lighting, Inc. v. Compco Corp., 311 F.2d 26 (7th Cir. 1962).

70. 376 U.S. at 237.

71. 376 U.S. at $230-31$.

72. 376 U.S. at 237.

73. 376 U.S. at 231.

74. Id. at 231 n.7.

The purpose of Congress to have national uniformity in patent and copyright 
role in the patent field, section two of the present Copyright Act expressly reserves to the states the power to protect the author of an unpublished work from unauthorized copying. ${ }^{75}$

A further power explicitly left to the states is the power to protect the public froin commercial deception. In Sears, the Court held that states may require that all goods be labelled so as to prevent confusion of the public as to their source. ${ }^{76}$ And in Compco, it pointed out that the states have power to "impose liability upon those who . . . deceive the public by palming off their copies as the original."77 Thus, traditional actions-those with the element of passing off-are still permitted. Moreover, the Court did not explicitly repudiate the misappropriation rationale of International News Service v. Associated Press. ${ }^{78}$

Despite the obvious intent to preclude state regulation of a subject that ordinarily would fall into the fields of patent and copyright, ${ }^{79}$ the reach of Sears and Compco is unclear. The two cases certainly preclude state protection of works which could have obtained federal protection under the present act but were published without doing so. On the other land, works which are constitutionally copyrightable but are not capable of protection under the current act arguably are not denied the protection of state law..$^{80}$

Some commentators, however, liave read Sears and Compco to preclude state protection of uncopyrightable sound recordings which have been publicly distributed so long as the duplicates are properly

laws can be inferred from . . . that section of the Copyright Act which expressly saves state protection of unpublished writings but does not include published writings ....

Id., citing 17 U.S.C. $\$ 2$ (1964).

75. 17 U.S.C. $\$ 2$ (1964) provides that: "Nothing in this title shall be construed to annul or limit the right of the author or proprietor of an unpublished work, at common law or in equity, to prevent the copying, or use of such unpublished work without his consent, and to obtain damages therefor."

76. 376 U.S. at 232.

77. 376 U.S. at 238.

78. 248 U.S. 215 (1918); see notes $25-29$ supra and accompanying text. While it may be argued that International. News Service was implicitly overruled, the Supreme Court's failure to articulate rational criteria to guide lower courts in the exercise of their power to regulate unfair competition makes such an implication unnecessary and undesirable.

79. In Sears Justice Black concluded that "because of the federal patent laws a State may not, when the article is unpatented and uncopyrighted, prohibit the copying of the article itself or award damages for such copying." 376 U.S. at 232-33.

80. "Has the Court spoken inferentially about such a case as Capitol Records where the work, the musical rendition, is not covered by the statute, rather than a case covered as to type but failing to qualify, as was the configuration in Sears and Compco?" Kaplan, An Unhurried View of Copyright, 66 Colum. I. RzV. 831, 839-40 (1966). Similarly, the Register of Copyrights has suggested only that Sears and Compco "may" affect protection against record piracy. 1965 Hearings, supra note 3, at 50 . 
labeled as those of the duplicator and not the original product. ${ }^{81}$ Since the Supreme Court did not decide what constitutes "publication" for purposes of divesting the states of power to grant common law protection under section two of the $\mathrm{Act}^{82}$ and did not explicitly overrule the unfair competition doctrine of International News Service, such an important and long-standing body of law should not be presuined to have been eliminated. ${ }^{83}$

Thus there are two major paths open to courts seeking to narrow or distinguish Sears and Compco so that protection can be given to phonograph records and other statutory non-copyrightables. First, as indicated above, articles which have not been "published" are still protectible under common law copyright. ${ }^{84}$ Sound recordings, if held to be within this category, could be protected from unauthorized duplication. ${ }^{85}$ Second, the Court's failure to repudiate the International News Service case and its explicit approval of the continuation of state jurisdiction over common law copyright leaves the misappropriation rationale a viable state doctrine. ${ }^{86}$ It can be argued that certain forms of misappropriation, such as the duplication of sound recordings, are still actionable under state law..$^{87}$

81. E.g., M. NIMMER, supra note 5, $\S 35,59$; Gamboni, supra note 16, at 57-70; Comment, Sound Recordings, Records, and Copyright, 33 ALBANY L. REV. 371, 385-87 (1969).

82. See text accompanying notes $90-110$ infra.

83. The Court has failed to deal with these issues in the seven years since Sears and Compco despite the fact that the lower courts have simply refused to construe Sears and Compco as precluding a state definition of publication [see part II, A infra] or as precluding the use of the misappropriation rationale to protect uncopyrightable sound records from unauthorized duplication. See part $\mathrm{Z}, \mathrm{B}$ infra.

Professor Nimmer has speculated that if the Supreme Court is ever faced with the issue it may well "shrink from applying the Sears-Compco rationale to record piracy." Nimmer, Copyright and Quasi-Copyright Protection for Characters, Titles and Phonograph Records, 59 TRADEMARK REP. 63, 75 (1969).

84. See Edgar H. Wood Assoc. v. Skene, 347 Mass. 351, 197 N.E.2d 886 (1964); M. NIMMER, supra note $5, \S 35$.

85. At least three courts have adopted this rationale in part in protecting sound recordings from piracy. Columbia Broadcasting Sys. v. Cartridge City, Ltd., 35 C.O. Bull. 87 (N.Y. Sup. Ct. 1966); Greater Recording Co. v. Stambler, 144 U.S.P.Q. 547 (N.Y. Sup. Ct. 1965); Capitol Records, Inc. v. Greatest Records, Inc., 43 Misc. 2d 878, 252 N.Y.S.2d 553 (Sup. Ct. 1964); accord, Edgar H. Wood Assoc. v. Skene, 347 Mass. 351, 197 N.E.2d 886 (1964); Columbia Broadcasting Sys. v. Documentaries Unlimited, Inc., 42 Misc. 2d 723, 248 N.Y.S.2d 809 (Sup. Ct. 1964); New York World's Fair 1964-1965 Corp. v. Colourpicture Publishers, Inc., 141 U.S.P.Q. 939 (N.Y. Sup. Ct.), aff'd, 21 App. Div. 2d 896, 251 N.Y.S.2d 885 (1964). But see Columbia Broadcasting Sys. v. DeCosta, 377 F.2d 315 (1st Cir.), cert. denied, 389 U.S. 1007 (1967).

86. See Goldstein, supra note 55, at 71-73.

87. Several conrts have held that protection against misappropriation of the plaintiff's property itself, as distinguished from copying the product as in the Sears and Compco cases, is not invalidated by those decisions. Cases dealing with sound re- 


\section{A. State Protection of "Non-Published" Writings After Sears and Compco}

Since pre-publication protection of all writings is available under present doctrines, ${ }^{88}$ the question of what law determines when "publication" occurs becomes most significant. ${ }^{89}$ In its broad dictum in Sears and Compco the Supreme Court did not decide whether publication is a federal or a state question. The trend in this century seems to have been toward allowing state courts to determine what constitutes publication for the purpose of divesting common law rights, while allowing federal law to deterunine what acts are sufficient to constitute publication required for investing statutory copyright. ${ }^{90}$ In the case of sound recordings this division of power is justifiable in spite of the implication of Sears and Compco to the contrary. ${ }^{91}$

cordings are: Tape Indus. Ass'n of America v. Younger, 316 F. Supp. 340 (S.D. Cal. 1970); Capitol Records, Inc. v. Erickson, 2 Cal. App. 3d 526, 82 Cal. Rptr. 798 (2d Dist. 1969); Greater Recording Co. v. Stambler, 144 U.S.P.Q. 547 (N.Y. Sup. Ct. 1965); Capitol Records, Inc. v. Greatest Records, Inc., 43 Misc. 2d 878, 252 N.Y.S.2d 553 (Sup. Ct. 1964). Professor Nimmer notes that "[t]here are a number of unreported trial court decisions in California to the saine effect." Nimmer, supra note 83, at 74 n.43. Cases dealing with subjects other than sound recordings are: Grove Press, Inc. v. Collectors Publication, Inc., 264 F. Supp. 603 (C.D. Cal. 1967); Pottstown Daily News Publishing Co. v. Pottstown Broadcasting Co., 247 F. Supp. 578 (E.D. Pa. 1965); Flainingo Telefilm Sales, Inc. v. United Artists Corp., 141 U.S.P.Q. 461 (N.Y. Sup. Ct.), rev'd on other grounds, 22 App. Div. 2d 778, 254 N.Y.S.2d 36 (1964); New York World's Fair 1964-1965 Corp. v. Colourpicture Publishers, Inc., 141 U.S.P.Q. 939 (N.Y. Sup. Ct.), aff'd, 21 App. Div. 2d 896, 251 N.Y.S.2d 885 (1964); Columbia Broadcasting Sys. v. Documentaries Unlimited, Inc., 42 Misc. 2d 723, 248 N.Y.S.2d 809 (Sup. Ct. 1964); cf. Press Publishing Co. v. Atlantic County Advertiser, Inc., 108 N.J. Super. 75, 260 A.2d 6 (N.J. Super. Ct. 1969). But cf. Columbia Broadcasting Sys. v. DeCosta, 377 F.2d 315 (1st Cir.), cert. denied, 389 U.S. 1007 (1967); G.P. Putnam's Sons v. Lancer Books, Inc., 239 F. Supp. 782 (S.D.N.Y. 1965).

88. See text accompanying notes 74-75 supra.

89. The prevailing state rule is that "sale of ... records does not constitute divestment of common law rights." M. NIMMER, supra note $5, \S 35$, at 145 . The federal rule, based upon RCA Mfg. Co. v. Whiteman, 114 F.2d 85 (2d Cir.), cert. denied, 311 U.S. 712 (1940) [see notes 34-36 supra and accompanying text], appears to be that sale of records does divest common law rights in the sound recording. It must be remeinbered that Whiteman was a broadcasting case as opposed to a record piracy case. But see Capitol Records, Inc. v. Mercury Records Corp., 221 F.2d 657 (2d Cir. 1955) (Hand, J., dissenting); see notes 56-59 supra and accompanying text.

90. See Kalodner \& Vance, The Relation Between Federal and State Protection of Literary and Artistic Property, 72 HARv. L. REv. 1079, 1091-96 (1959). Compare Blanc v. Lantz, 83 U.S.P.Q. 137 (L.A. County Super. Ct. 1949) with Atlantic Monthly Co. v. Post Publishing Co., 27 F.2d 556 (D. Mass. 1928).

91. The notion that there is a federal policy which precludes state protection of any article not protected under the Copyright Act implies federal regulation of the concept of publication. Since non-published articles are protectible by the states under section 2 of the Act, state definitiou of publication would allow the states to determine what is within the public domain and hence withm the federally preempted field. This might be contrary to the supremacy clause of the Constitution.

In addition, it has been suggested by Professor Nimmer that the Sears-Compco 
If a federal definition is required and the public sale of phonograph records is held to divest performers and record manufacturers of any rights in the performances embodied in them, the sole result would be a diversion of profits to pirates unburdened by the expenses of producing the music. ${ }^{92}$ Such a result should not be allowed. ${ }^{03}$ Indeed, it has become clear since Sears and Compco that courts have not read those cases to preclude state definition of publication and hence state protection of some uncopyrighted material even after public sale where the alternative is a denial of all rights in the work. ${ }^{94}$

In Edgar H. Wood Assoc. v. Skelne, ${ }^{05}$ decided shortly after Sears and Compco, the Massachusetts Supreme Judicial Court, relying on precedent from other states, and making no reference to federal decisions to the contrary, ${ }^{96}$ leld that neither public filing of architects' plans nor construction of a building constituted a divestive publication. The court held that Sears and Compco did not deprive the states of the power to regulate common law copyright and iguored the fact that the plans could have been copyrighted under section 12 of the federal act. ${ }^{.7}$

Similarly, a New York court just two months later, in a case involving the unauthorized manufacture and sale of Beatle recordings, lield that the law of New York was still " that where the originator . . . of records of performances by musical artists puts those records on

thesis is more or less an embodiment of Judge Hand's doctrine in his Whiteman and Capitol Records opinions in which he argued that the definition of publication must be a question of federal law for all works which are writings within the constitutional clause. M. NIMMER, supra note $5, \S 35$, at 145.2 . It is significant in this respect that Mr. Justice Black cited G. Ricordi \& Co. v. Haendler, 194 F.2d 914 (2d Cir. 1952), a copyright decision written by Judge Hand, in support of his statement that "because of the federal patent laws a State may not, when the article is unpatented and uncopyrighted, prohibit the copying." Sears, Roebuck \& Co. v. Stiffel Co., 376 U.S. 225, 231 (1964). Professor Goldstein has stated, however, that "Ricordi, neither in its holding nor in its logic, supports the pre-emptive proposition for which Mr. Justice Black cited it in Sears . . . " Goldstein, supra note 55, at $61 \mathrm{n.73.}$

92. For example: studio costs; payments to engineers and technicians, to vocalists, to arrangers, to salaried and independent producers; investment in publicity, promotion, and distribntion; maintenance of facilities and equipment; royalties to the performing artists and usually the music publishers and composers; and, payroll, withholding taxes, and other various overhead expenses, none of which are paid by the unauthorized duplicator.

93. Professor Kaplan has argued that "[f]orfeiture is a drastic thing, and a court may prefer to leave the composer with full common-law protection if the only perceived alternative is to deprive him of all rights." Kaplan, Publication in Copyright Law: The Question of Phonograph Records, 103 U. PA. L. Rev. 469, 487 (1955). Although Professor Kaplan was discussing the problem of publication regarding inusical compositions, the analogy to performers is obvious.

94. See cases cited note 85 supra.

95. 347 Mass. 351,197 N.E.2d 886 (1964).

96. Id. at 356,197 N.E.2d at 890 .

97. Id. 
public sale, his act does not constitute a dedication of the right to copy and sell the records." "98

The preemption rationale of Sears and Compco in regard to the definition of publication inust be discounted because of the Court's failure to deal concretely with the broad issues which it raised. Its failure to expressly state a rule of total federal preemption in the field of copyriglit, together with its explicit approval of continued state jurisdiction over common law copyright under section 2 of the Act, make continued state protection feasible. As Professor Goldstein has stated:

The divergence between Supreme Court pronouncements and lower court practice is attributable to the Court's exclusive reliance upon policy postulates; the exigencies of lower court decision-making require that attention be paid to common law tenets, which, more often than not, cannot square with the Court's broad assumptions. While both the dicta and logic of Sears and Compo assert the proposition that states are barred from affording remedies which benefit subject matter that federal copyright and patent policy requires should have no benefits, the Court made no attempt to articulate rational criteria which can serve to discriminate between allowable and intolerable state regulations . . . .99

State definition of publication in the area of sound recordings seems justified since these works are denied federal protection solely as a result of the failure of Congress to enact a new copyright statute granting such undeniably necessary protection after more than 60 years of inequity under the present law. ${ }^{100}$ Courts have struggled to develop common law protection for performers and record manufacturers and "[t]he usual arguments in favor of the user and against the creatorthe fear of monopoly and the public interest in broad disseminationare singularly unappealing as grounds for giving a free hand to record pirates." 101

One objection to state protection of phonograpli records is

98. Capitol Records, Inc. v. Greatest Records, Inc., 43 Misc. 2d 878, 882, 252 N.Y.S.2d 553, 557 (Sup. Ct. 1964).

99. Goldstein, supra note 55 , at 65 .

100. For a history of legislative efforts to enact a provision for the copyright of sound recordings see Senate StudiEs, supra note 5, at 21-37. Sound recordingś are copyrightable under the revision bill. S. 543, 91st Cong., 1st Sess. § 102(7) (1969).

101. Nimmer, supra note 83, at 75. Newsweek inagazine has reported that record piracy has become a major threat to the record industry, especially in the area of cartridge tapes, and that the unauthorized duplicators are trying desperately to undermine the present common law legal protection afforded to recording artists and record manufacturers. See NewsweEr, Oct. 5, 1970, at 71.

In Capitol Records, Inc. v. Erickson, 2 Cal. App. 3d 526, 82 Cal. Rptr. 798 (2d Dist. 1969), one duplicator admitted that it was his intention in manufacturing and distributing pirated tapes "to test the law" and challenge state protection of sound recordings after Sears and Compco. Id. at 530, 82 Cal. Rptr. at 800. 
that it is contrary to the "limited times" provision of the constitutional clause. The argument is that it would allow perpetual protection of a recording. This provision, however, should not be applicable in the record context. First, such a use of the doctrine "opposes many years of practice and general assumption"102 as the provision has generally not been applied in such cases. ${ }^{103}$ Second, "[t]he words of the clause do not refer to the states."104 Finally, the underlying conceptual basis for the clause does not apply to the acts of record pirates. ${ }^{105}$ The purpose of the "limited times" provision considered together with the broad purpose of the constitutional clause to promote the progress of science and useful arts appears to be "aimed at freeing the work after a reasonable period so that others will be encouraged to use materials therein in the process of creating their own work."106 This rationale is certainly not applicable to the unauthorized duplication of a creator's efforts. There is no social gain in eliminating the protection of recorded works so that they can be mechanically reproduced by others and sold to the detriment of their creator. While the limited times provision does eventually destroy the creator's right to exclusive return for his creation, record piracy precludes even a minimal period of protection.

Further, the goal of free and open competition envisioned by Sears and Compco is hardly promoted by allowing the piracy of recorded works. Because the record pirate has none of the expenses of production $^{107}$ it is impossible for the performer and legitimate manufacturer to compete. The public benefit in receiving cheaper and lower quality ${ }^{108}$ recordings hardly outweighs the total loss in income to the artist who has created the performance and the record manufacturer who produced it.

It is true that a definition of publication which does not include the sale of records to the general public is contrary to the prevailing copy-

102. Kalodner \& Vance, supra note 90, at 1085.

103. But see RCA Mfg. Co. v. Whiteman, 114 F.2d 86 (2d Cir.), cert. denied, 311 U.S. 712 (1940).

104. Kalodner \& Vance, supra note 90 , at $\mathbf{1 0 8 5}$.

105. See Comment, The Twilight Zone: Meanderings in the Area of Performers' Rights, 9 U.C.L.A.L. REv. 819, 857-58 (1962).

106. Id. The doctrine of fair use which allows the "innocent" copying of limited parts of certain works also serves this purpose to some extent, but it also protects the author's right to be compensated for his work for the statutory period and protects him from any substantial encroachment upon the potential market for or value of the copyrighted work. See House CoMm. ON THE JUdiciary, Copyright LaW Revision, H.R. REP. No. 83, 90th Cong., 1st Sess. 29-30 (1967).

107. See note 92 supra.

108. Pirated recordings are generally of lower quality because they are recordings of recordings as opposed to recordings of live music. Like photostatic copies of photostatic copies, they are of necessity less clear. In addition, the equipment of most rccord pirates is inexpensive and often substandard. LIFE, Apr. 17, 1970, at 15. 
right definition of that term, ${ }^{109}$ but such a definition has been necessitated by the absence of statutory protection for a valuable property interest. Unlike the situation with regard to the lighting fixtures in Sears and Compco, it is impossible to acquire federal protection for sound recordings under the present Copyright Act. If state law cannot provide protection, there will be an open season for record pirates. $^{110}$

It is thus not unreasonable for lower courts to cling to the common law definition of publication in performers' rights cases in spite of Sears' and Compco's implication of federal preemption. It was the Supreme Court's failure to issue a clear ruling on this poimt that opened the door for continued state definition of publication. If the Court wishes to change this rule it will lrave to do so more explicitly in a future decision.

\section{B. State Protection Against Unfair Competition and Misappropriation}

Despite the fact that Sears and Compco struck down the use of Illinois' law of unfair competition to protect unpatentable articles because it granted a monopoly where federal law declared that none should exist, many courts have continued to protect a wide variety of statutorily uncopyrightable articles under the doctrine of misappropriation. ${ }^{111}$ This practice is also the result of the Court's failure clearly to repudiate the International News Service case, which is the basis for the doctrine, its blanket approval of state jurisdiction over common law copyright, ${ }^{112}$ and the reluctance of lower court judges to give legal sanction to grossly unfair practices.

Both state and lower federal courts have read Sears and Compco to prohibit only state injunctions against copying, but not appropriation

109. Nimmer, supra note 83 , at 74 ; see M. NIMMER, supra note 5 , $\$ 49,51.2$.

110. The definition of publication is certainly not so invariable that it cannot accommodate this exception in light of the failure of the Copyright Act to protect sound recordings. As Professor Kaplan stated more than 15 years ago:

The rules which together comprise the common-law copyright are certainly no more fixed or invariant than other rules of the common law; they must be intelligently shaped and apphed to the emergent and developing facts of intellectual production. The existence and the economic and other consequences of the Copyriglit Code are themselves important facts which shonld not be overlooked in the decision of common-law cases. Kaplan, supra note 93, at 487 (footnotes omitted).

It is because the Copyright Act demes any protection to sound recordings that the common law definition of pnblication was shaped around the performer's and record manufacturer's intent to reserve his rights in his work after public sale rather than on the more traditional rule of publication by general public distribntion.

111. See cases cited note 87 supra.

112. Sears, Roebuck \& Co. v. Stiffel Co., 376 U.S. 225, 231 n.7 (1964). 
"for the commercial advantage of one person of a benefit or "property right' belonging to another." Under this doctrine, for example, another performer could imitate or copy the style of a Frank Sinatra recording in every detail and sell records in competition with the original with complete impunity so long as he did not pass himself off as Mr. Sinatra. ${ }^{114}$ This activity would be protected under traditional copyright notions, and the Sears-Compco thesis would prohibit any state interference with the copier's right to coinpete. But this activity clearly differs from re-recording a Sinatra performance and selling it at a much lower price than the original. In the first case there is competition between two performers and two recording companies. In the second case Sinatra and the original inanufacturer are forced to compete against themselves at a great disadvantage. The pirate simply waits until the large expenses involved in recording a song and promoting it have been paid by the legitimate manufacturer, then he re-records the work, sells it at a fraction of the original's cost, and reaps a big profit at the artist's and manufacturer's expense. This type of competition could seriously harin the record imdustry.

Drawing a line between copying and appropriation may appear to be "a distinction without a difference"115 to some, but the Supreine Court failed to take a clear opportunity to stop it. It denied certiorari in Flexitized, Inc. v. National Flexitized Corp. ${ }^{110}$ where the Court of Appeals for the Second Circuit had granted relief for unfair competition in a trademark infringement case even though plaintiff's trademark had been found invalid. In addition, there was no showing of secondary meaning or palming off. The court held that under the International News Service doctrine, as construed by the New York courts, relief could be awarded merely by a showing of misappropriation. ${ }^{117}$ While the Supreme Court's refusal to hear this case on appeal cannot be taken as approval of the misappropriation rationale, it may lend support to the argument that the Court does not see any great danger in its continued viability.

113. Flexitized, Inc. v. National Flexitized Corp., 335 F.2d 774, 782 (2d Cir. 1964), cert. denied, 380 U.S. 913 (1965).

114. Senate Studies 10; see Sinatra v. Goodyear Tire \& Rubber Co., 435 F.2d 711 (9th Cir. 1970), cert. denied, 91 S. Ct. 1376 (April 19, 1971); Davis v. Trans World Airlines, 297 F. Supp. 1145, 1147 (C.D. Cal. 1969); Supreme Records, Inc. v. Decca Records, Inc., 90 F. Supp. 904, 908-09 (S.D. Cal. 1950); cf. Lahr v. Adell Chem. Co., 300 F.2d 256, 259 (1st Cir. 1962). But see Supreme Records, Inc. v. Decca Records, Inc., supra at 909 (dictum).

115. Nimmer, supra note 83 , at 74.

116. 335 F.2d 774 (2d Cir. 1964), cert. denied, 380 U.S. 913 (1965).

117. 335 F.2d at 781. But see Spangler Candy Co. v. Crystal Pure Candy Co., 353 F.2d 641 (7th Cir. 1965). 
Other lower courts have used the misappropriation rationale to protect statutory non-copyrightables of various types. Courts enjoined the unauthorized duplication of sound recordings in Capitol Records, Inc. v. Erickson, ${ }^{118}$ and Capitol Records, Inc. v. Greatest Records, Inc. ${ }^{110}$ In both cases the defendants liad made recordings directly from plaintiff's records of popular music stars and were selling them on cartridge tapes and phonograph records under their own label at a mucl lower price than the plaintiff was selling its own recordings. Significantly, in the Erickson case the defendants affixed a warning on their label that the product was not the original. ${ }^{120}$ Defendants had also altered the order of the performances found on the Capitol albums. ${ }^{121}$ One of the defendants informed a national record distributor that it was their intention to "test the law"122 and the legend on the labels was apparently part of this plan. The defendants' contention was that Sears and Compco preclude any state protection, on the theory of unfair competition or otherwise, against the reproducing of phonograph records. ${ }^{123}$

After a thorough consideration of Sears and Compco and their progeny in the field of non-copyriglitable material, the California court of appeal upheld a preliminary injunction restraining defendants, on the ground of unfair competition, froin transcribing any performances embodied in the phonograph recordings produced and sold by Capitol. ${ }^{124}$ The court frained the issue as one of the respective rights and duties of competitors in business, rather than the rights of the record manufacturer vis-à-vis the public. ${ }^{125}$ While the defendants laad labelled their cartridges as duplicates, they had "appropriated the product itselfperformances embodied on the records. . . [They] appropriated

118. 2 Cal. App. 3d 526, 82 Cal. Rptr. 798 (2d Dist. 1969).

119. 43 Misc. 2d 878, 252 N.Y.S.2d 553 (Sup. Ct. 1964); see Tape Indus. Ass'n of America v. Younger, 316 F. Supp. 340 (S.D. Cal. 1970); Greater Recording Co. v. Stambler, 144 U.S.P.Q. 547 (N.Y. Sup. Ct. 1965); accord, Flamingo Telefilm Sales, Inc. v. United Artists Corp., 141 U.S.P.Q. 461 (Sup. Ct.), rev'd on other grounds, 22 App. Div. 2d 778, 254 N.Y.S.2d 36 (1964); Columbia Broadcasting Sys. v. Documentaries Unlimited, Inc., 42 Misc. 2d 723, 248 N.Y.S.2d 809 (Sup. Ct. 1964).

120. No relationship of any kind exists between Phoenix and the original recording company nor between this recording and the original recording artist. This tape is not produced under a license of any kind from the original coinpany nor the recording artist(s) and neither the original recording company nor artist(s) receives a fee or royalty of any kind from Phoenix. Permission to produce this tape lias not been sought nor obtained from any party whatsoever.

2 Cal. App. 3d at 528, $82 \mathrm{Cal}$. Rptr. at 799.

121. Id. at 530, 82 Cal. Rptr. at 800 .

122. Id.

123. Id.

124. Id. at 537-38, 82 Cal. Rptr. at 806.

125. Id. at 538, 82 Cal. Rptr. at 806. 
the title of the performances ... and ... the name of the recording artists. . .."128 The court held that a finding of unfair competition in such circumstances is warranted in order to encourage invention and free competition. ${ }^{127}$

Similarly, a three-judge federal district court, citing Erickson, recently held that a state law prohibiting record and tape piracy was not preempted by the supremacy clause of the United States Constitution, or by the Sears and Compco decisons. ${ }^{128}$ The court held that the taking of the product itself, as opposed to copying or imitating it, is still actionable under state unfair competition laws. ${ }^{120}$

The precise issue of federal preemption has been discussed in relation to the misappropriation doctrine in other contexts. A federal district court refused to hold that International News Service and its misappropriation rationale had been overruled by Sears and Compco in Potts. town Daily News Publishing Co. v. Pottstown Broadcasting Co. ${ }^{180}$ The court found that the pirating of news items was a violation of a property right which would give rise to an action for unfair competition in any state court. Judge Body distinguished Sears as a case concerned with the copying of an unpatented and uncopyrighted product while Pottstown involved an unwarranted appropriation of plaintiff's news items. In granting injunctive relief, the court noted that:

[A]ny other construction [of Sears and Compco] would leave a glaring loophole in the law.

.. . Men of conscience would hardly condone such an inequitable result and we, as a court of conscience, will not subscribe to such a conclusion unless the Supreme Court enlightens us with a clear ruling on this specific problem. ${ }^{131}$

\section{Id. (citations omitted).}

127. It is reasonable to conclude that permitting such appropriation would discourage invention and free competition-and that those engaged in the recording industry, would be inclined not to utilize their skill and efforts, and expend large amounts of money, in producing unique recordings, but would wait for a recording to be produced, and then duplicate it and sell it, at maximuin profit and with minimum effort and expense.

Id. In the Greatest Records case, the court held that Sears and Compco "are not applicable to the subject matter and devious conduct of defendants. . . . The only issue present herein is whether defendants may appropriate the performances contained on plaintiff's phonograph records." 43 Misc. $2 \mathrm{~d}$ at 880,252 N.Y.S.2d at 555 (court's emphasis). "Neither of those learned decisions stands for the proposition that this plaintiff is not entitled to protection against the unauthorized appropriation, reproduction or duplication of the actual performances contained in its records." Id. at 881,252 N.Y.S.2d at 556.

128. Tape Indus. Ass'n of America v. Younger, 316 F. Supp. 340, 351 (C.D. Cal. 1970).

129. Id.

130. 247 F. Supp. 578 (E.D. Pa. 1965). But see Columbia Broadcasting Sys. v. DeCosta, 377 F.2d 315, 318 (1st Cir.), cert. denied, 389 U.S. 1007 (1967).

131. 247 F. Supp. at 581. 
Significantly, in Grove Press, Inc. v. Collectors Publications, Inc., ${ }^{132}$ a federal district court, citing Internal News Service and avoiding Judge Hand's Ricordi opinion, refused to allow a defendant to inanufacture and sell photo-lithographed copies of plaintiff's type-set edition of a public domain work. ${ }^{133}$ The court held that while the words of an uncopyrighted work are in the public domain and may be copied by anyone, ${ }^{134}$ this right does not include a license to appropriate the work of another. ${ }^{135}$ Judge Hill concluded that the defendant's version of the work was more than mere copying of that of the plaintiff. ${ }^{136}$

In view of Plaintiff's expenditure of substantial sums in setting type and engraving plates, it would constitute unfair competition for Defendants to appropriate the value and benefit of such expenditures to themselves by photographing and reproducing plaintiff's book through the offset-lithography process, thereby cutting their own costs and obtaiming an unfair competitive advantage. ${ }^{137}$

The judge stated bluntly: "Unfair appropriation of the property of a competitor is unfair competition and redressable in a situation of this kind despite the holdings in Sears and Compco. . . ."138

Thus, the misappropration rationale is still a viable alternative to the abandonment of recorded performances to record piracy. The appropriation of the name of the inusical artist, the title of the album or group of performances, and the actual music itself should be protected under state law. While the common law remedies are far froin being adequate to control the burgeoning practice of record piracy, ${ }^{139}$ they

132. 264 F. Supp. 603 (C.D. Cal. 1967), a case very similar on its facts to G. Ricordi \& Co. v. Haendler, 194 F.2d 914 (2d Cir. 1952), where Judge Learned Hand refused to enjoin the photographic reproduction of plaintiff's libretto and score of an opera after the copyright on the opera had expired.

133. $264 \mathrm{~F}$. Supp. at 606-07.

134. Id. at 606.

135. Id.

136. Id. at 606-07.

137. Id.

138. Id. at 606 .

139. It has been said that the unfair competition theory is an ad hoc approach to the problems of the record industry which is used "to fill the interstices occasioned by the application of an outdated copyright law in an expanding society." Goldstein, Copyrighting the New Music, 17 Buffalo L. Rev. 355, 369 (1968). The saine may be said of cominon law copyright. As such, both leave much to be desired. First, these approaches cause a lack of uniformity across the nation in that each state is free to define its own rules. Second, the injunction against unauthorized duplication, if granted, will prevent the pirate from duplicating only the specific plantiff's recordings and only in the specific jurisdiction. Third, because of the relatively slort life of most hit records, the real harm to the performer and manufacturer may already be done before any remedy can be obtained. Finally, it is most difficult for the performer and manufacturer to prove their damages even where relief is granted. 
alone are available at the present time and should be utilized until a better solution is available. ${ }^{140}$

\section{III}

\section{The Rights of Performers and Record Manufacturers Under the Proposed ReVision Bill}

The solution to the present inadequacies of the common law remedies and their conflict with the Sears-Compco rationale lies to a great extent in the proposed Revision Bill which has been introduced in Congress. ${ }^{141}$ This bill, representing the culmination of a revision program which began under the supervision of the Copyright Office in 1955, ${ }^{142}$ will revise the present Act in its entirety and establish exclusive federal preemption of literary property. ${ }^{143}$ Its provisions regarding the protecof phonograph records recognize for the first time copyright protection for the performer and manufacturer just as it is given to the coinposer and publisher of the inusic itself. The bill will not only accord federal statutory protection to sound recordings against unauthorized duplication, but also will recognize the right of performers and record companies to be compensated for the playing of their works in performances for profit.

In the Revision Bill, "sound recordings"144 appear in section $102(7)$ as a separate category of copyrightable work. ${ }^{145}$ The copy-

140. The primary reason Congress did not enact legislation granting protection to sound recordings in the 1930's appears to have been its fear that a few large publishing companies of that era would be able to monopolize all music. Diamond, supra note 35 , at $842-43$. In addition, it was thought by some that such protection would not be constitutional in light of White-Smith Music Publishing Co. v. Apollo Co., 209 U.S. 1 (1908), which held that a sound recording was not a copy of the underlying musical composition. From this it was inferred that they could not be writings. SENATE STUDIEs, supra note 5, at 4-5.

141. S. 543, 91st Cong., 1st Sess. (1969) [hereinafter cited as S. 543].

142. See Diamond, supra note 35 , at 847.

143. See S. 543, \& 301 .

144. Section 101 of the revision bill defines sound recordings as:

works that result from the fixation of a series of musical, spoken, or other sounds, but not mcluding the sounds accompanying a motion picture or other audiovisual work; regardless of the nature of the material objects, such as disks, tapes, or other phonorecords, in which they are embodied.

S.543, $\$ 101$. These inust be distinguished from "phonorecords" which are defined in section 101 as:

the material objects in which sounds other than those accompanying a motion picture or other audiovisual work, are fixed by any method now known or later developed, and from which the sounds can be perceived, reproduced, or otherwise communicated either directly or with the aid of a machine or device. The term phonorecords includes the material object in which the sounds are first fixed.

145. The copyright in the sound recording must be distinguished from that which may also exist in any musical, literary or dramatic work embodied on the record. The usual phonorecord of a popular song will thus constitute the reproduction of two independently copyrighted works; the song, and the sound recording of it. 
right extends to the exclusive right to reproduce the work, to distribute phonorecords of it to the public, and to perform it publicly. ${ }^{148}$ The rights to reproduce and perform the work, however, are limited to:

the rights to duplicate the sound recording in the form of phonorecords that directly or indirectly recapture the actual sounds fixed in the recording, and to perform those actual sounds publicly. This right does not extend to the inaking or duplication of another sound recording that is an independent fixation of other sounds, or the performance of other sounds, even though such sounds imitate or simulate those in the copyrighted sound recording. ${ }^{147}$

In this sense the Bill codifies the exisiting law which allows imitation to the extent that the imitator does not pass himself off as the original. ${ }^{148}$ Under the Revision Bill deceptive trade practices such as passing off would still be actionable at common law. ${ }^{149}$ Of course a third party will ordinarily have the right to make a recording of the composition embodied in another's sound recording under the coinpulsory license of section 114.150 Reproduction of the actual sounds of the recording itself, however, is an infringement which renders the copier liable to all the remedies provided by the Act. ${ }^{151}$ This limitation of the sound recording copyright is desirable in order to promote public access to popular musical material. The artist and the recorder are given protection against the pirating of their work, yet their nonopoly does not extend into the area of musical style and arrangennent which might severely hamper creation in the field. Any artist or record manufacturer who seeks to imitate the performance of another must also bear the expense of producing and promoting his own work. Freeloading off the work of another is eliminated, yet the courts are not required to take on the delicate task of comparing the styles, arrangements and tones of one performer witli those of another.

In addition, this limitation would be parallel to present law in regard to photographs, motion pictures and related works. To mechanically copy another's photograpli of the Golden Gate Bridge at sunset would be a clear infringement of his copyright. ${ }^{152}$ To take a substantially similar photograph of the bridge at another time, however, would be to create another copyrightable and non-infringing work. ${ }^{153}$ While the subject is basically the same; the works are different. The

146. S. $543, \S \S 106(1),(2),(3)$.

147. Id. $\S 114(\mathrm{~b})$.

148. See text accompanying note 114 supra.

149. S. $543, \S 301$.

150. Id. $\$ 114$; see notes $175-85$ infra and accompanying text.

151. See S. 543 , §§ 501-08.

152. See Burrow-Giles Lithographic Co. v. Sarony, 111 U.S. 53 (1884).

153. See Diamond, supra note 35 , at 863 . 
bridge is in the public domain and may be photographed by anyone. ${ }^{164}$ In the same way, a performer may not take a public domain or copyrighted song and gain the exclusive riglt to perform it in a particular way. His performance itself is his own creation; his rendition of the song is an embellishment which may be copied by another who is able to duplicate the same conditions and record the same song.

Even if another performer or manufacturer duplicates a popular recorded performance to a high degree, the original artist and record company are not likely to be harmed. The copier's record is not the same as the original. It is not, for example, a Frank Simatra record even though it sounds very similar. The buyer cannot get the Sinatra record itself from anyone other than the original recorder, and the copier cannot sell his imitation for a substantially lower price anyway due to the expenses he must meet to produce it. At the same time, the public is able to benefit from the development and competition of popular music styles. ${ }^{155}$

In addition to the sound recording copyright designed to prevent the unauthorized duplication of these works, performance rights for the artists and record companies, similar to those extended to composers and publishers under the present act, ${ }^{156}$ are provided for in the Revision Bill. While the right to prevent unauthorized duplication has been a part of the revision prograin for many years, the performance right was previously too controversial to gain inclusion, ${ }^{157}$ and it had not received any major support in the revision program's earlier years. During the 1965 House subcommittee hearings, the American Federation of Musicians became the first and only group to advocate sucli a right. ${ }^{168}$ Prior to that date, performers as sucli did not liave an organization to represent them, and the phonograph record imdustry was occupied with its own battle: first, to preserve the compulsory license provisions

154. Cf. Gross v. Seligman, 212 F. 930 (2d Cir. 1914).

155. This might also be true if the original is allowed to be pirated and sold for lower prices. However, the burden of that practice on the creator would be so heavy that new developments would be stifled and the net result would be no creation at all.

156. 17 U.S.C. $\$ 1$ (e), 101(e) (1964).

157. The Register of Copyrights stated in 1965 that the denial of performance rights in the revision bill was "not [a] mere expediency, but . . . a necessary and conscious recognition of what will and will not be accepted in this country today in this evolving field." He told a House subcommittee that if such a proposal were to be given favorable consideration "I am sure you would see a wave of protest that would be likely to tear this bill apart." 1965 Hearings, supra note 3, at 1863. See Diamond, supra note 35 , at $864-65$.

158. 1965 Hearings 1387-1405. Alan Livingston, President of Capitol Records, also spoke in favor of a performance right. Id. at 946-63. See Diamond, supra note 35, at 864. 
whose deletion had been recommended by the Register of Copyrights, and then to combat the proposed increase in the royalty rate. ${ }^{159}$

During the 1967 Senate subcommittee hearimgs, however, a rather massive effort was made to include a performance right for sound recordings in the Revision Bill. Senator Harrison A. Williams, Jr. introduced an amendment to the Senate bill which would have establislied a performing rights system. ${ }^{160}$ Representatives of the American Federation of Musicians, ${ }^{101}$ the Record Industry Association of Amer$\mathrm{ica}_{,}{ }^{102}$ and the newly formed National Committee for the Recording Arts $^{103}$ (which represents many well-known recording artists) all supported recognition of a performance right and spoke in favor of the Williams amendment. In essence they argued that:

the commercial value of a musical composition is created largely by the record manufacturer and the performing artists, who get no compensation from the use of their records by radio stations and other users, although the music publishers do collect royalties when their musical works are performed publicly for profit even though the performance more often than not consists of playing a phonograph record. ${ }^{164}$

Most songs would be practically worthless without a popular interpretation on record. The composers and publishers are paid each time the composition embodied in a sound recording is played on the radio or television, but the artist who made it popular, and whose name is sold to and identified with the commercial sponsors, receives nothing.

In addition, the lack of a performance royalty leads to a one-sided production emphasizing "teenage" music. Currently the record industry is forced to concentrate on rock-and-roll in search of fast, large sales and quick returns. ${ }^{165}$ Simce the only means of profit for the performer and record company is the sale of records, the music recorded is designed for a specialized buying market-the teenager-and that means "rock music". ${ }^{166}$ "Classical music is no longer profitable to record; yet it is performed constantly on radio, AM and FM, on sponsored programs, and it has a wide histening audience which for the most

159. Diamond, supra note 35, at 864; see Helfer, supra note 30 , at 165.

160. Amendment No. 9 to S. 543.

161. Hearings on S. 597 Before the Subcomm. on Patents, Trademarks, and Copyrights of the Senate Comm. on the Judiciary, 90th Cong., 1st Sess., 793, 1076 (1967) [hereinafter cited as 1967 Hearings].

162. E.g., id. at 494-504, 505-09, 532-35.

163. E.g., id. at 540-42.

164. Diamond, supra note 35 , at 865.

165. Testimony of Alan Livingston, President of Capitol Records, 1967 Hearings 503.

166. Id. at 503-04. 
part does not buy records." ${ }^{167}$ The result of the lack of a performance right is that many excellent songs are not recorded because the artists and record manufacturers will receive no compensation no matter how popular their rendition might become and how much it might be played on the radio. Finally, nearly all commercially important nations of the free world recognize the principle that sound recordings cannot be performed publicly without making some compensation for the privilege. ${ }^{188}$ The United States, by not recognizing a performers' right, is behind the times and prevents its own artists from being protected under foreign statutes which delnand reciprocity. ${ }^{160}$

Opposition to the proposal came mainly from the broadcasting, ${ }^{170}$ juke box, ${ }^{171}$ and the songwriter-publishing industries. ${ }^{172}$ Basically the objections of these groups were financially inotivated. ${ }^{173}$ The broadcasters and juke box operators don't want to pay out any additional royalties, and the pubhishers and coinposers don't want to share those which are paid out. Such commercial arguments are not persuasive, however, in view of the purpose of the entire copyright system which is to "protect certain types of intellectual property by affording a monopoly for a limited time period. That monopoly may be profitably employed by requiring others to pay for the privilege of publicly performing for profit that which is protected."174

In April, 1969, Senator Wilhams again introduced his "performer's right" amendment, and on Deceinber 10,1969, a similar provision was finally adopted by the subcommittee on Patents, Trademarks, and Copyrights of the Senate Committee on the Judiciary and added to the Revision Bill. ${ }^{175}$ The exclusive right to perform a copyrighted sound recording publicly is limited, however, by the compulsory license provision, section 114(c). ${ }^{176}$ Once phonorecords of the sound recording

167. Id. at 504 .

168. Id. at 508. See Diamond, supra note 35, at 866.

169. For example, in Denmark, payment is made only for the performance of recordings originating in Denmark itself or in a country which grants reciprocal rights to recordings of Danish origin. As a result, no payment is made for the use of U.S. recordings there. Denmark presently pays for less than 25 percent of recorded performances, and we can be certain that a substantial portion of the uncompensated balance is of U.S. origin. Denmark is a rather small country but it has a modern computerized system for the administration of performing rights in sound recording and Denmark's experience is influencing other countries.

1967 Hearings 508.

170. Id. at 863-71.

171. Id. at $1087-89$.

172. Id. at 875 .

173. See Diamond, supra note 35, at 867; Helfer, supra note 30, at 161-64.

174. Helfer, supra note 30 , at 163.

175. S. 543, \& 114 .

176. Juke box operators [id. $\S 116]$ and cable systems [id. $\S 111]$ are not covered by this section. 
have been distributed to the public under the authority of the copyright owner, any person who wishes to obtain a compulsory license to perform it may do so if he complies with the provisions of section 114 .

Section 114(c)(2) contains detailed provisions for applying for and obtaining the license from the Copyright Office. ${ }^{177}$ Sections 114(c)(3) and (4) allow negotiated licenses to be substituted for the compulsory license.

Section 114(c)(4) provides for a minimum royalty rate to be computed on either a blanket or a prorated basis. For radio and television stations licensed by the FCC the blanket rate is two percent of net receipts from advertising sponsors. The prorated rate is a fraction of two percent of the net receipts based upon a formula which is to take into account the amount of the station's commercial time devoted to playing copyrighted sound recordings. ${ }^{178}$ The rate for background music services and other transmitters is two percent of gross receipts with the same proration option. ${ }^{179}$

The royalties collected by the Copyright Office are to be distributed eacl year by the Register of Copyrights to those who show that they are entitled to the fees. ${ }^{180}$ For the purposes of the statute, one half of the royalties are to be paid to the copyright owners and one half to the performers. ${ }^{181}$ The claimants are entitled to agree among themselves, however, as to the proportionate division of the royalties. ${ }^{182}$ They may also lump their claims together and file them jointly as a simgle claim, or may designate a common agent to receive payment on their behalf, such as a performance rights society. ${ }^{183}$ The Revision Bill also makes provision for a copyright royalty tribunal which would determine controveries as to the distribution of royalties, and would assure that the royalty rates continue to be reasonable. ${ }^{184}$

This compulsory license is very similar to the present provision of

177. S.543, $\S 114(\mathrm{c})(2)$. It is probable, however, that a licensing organization similar to the American Society of Composers, Authors and Publishers (ASCAP) and Broadcast Music, Incorporated (BMI) will be formed by the recording industry and the performing artists to administer the licensing system. 1967 Hearings 505; see Finkelstein, ASCAP AS An Example of the Clearing House System in Operation, 14 BuLr. COPYRIGHT SOC'Y 2 (1966).

178. S. 543, \&114(c)(4)(A). Broadcast stations with gross receipts from advertising sponsors of less than $\$ 25,000$ during the applicable annual period are exempt under section $114(d)(1)$.

179. Id. $\$ 114(\mathrm{c})(4)(B)$. Background music services and other transmitters of sound recordings with gross receipts of less than $\$ 10,000$ are exempt under section $114(d)(2)$.

180. Id. $\S 114(\mathrm{e})(2)$.

181. 1d. § 114(e)(3); see note 200 infra.

182. S. 543 , \& $114(\mathrm{e})(1)$.

183. Id.

184. Id. $\S 114(\mathrm{e})(2) ;$ see id. $\S \S 802-07$. 
the Copyriglit Act for composers and publislers, ${ }^{185}$ and is beneficial to all concerned. The artist receives compensation for his performance and the public receives access to all recorded performances once the author allows them to be distributed. He knows that once his work is distributed for public performance lis rights are limited. This he must accept in order to profit from his artistic creation.

This leads, however, to the major omission in the Revision Bill in regard to the sound recording copyright. The proposed law does not specify the status of recordings existing at the time it goes into effect. Section 301 of the Bill is designed to entirely preempt the field of copyright: it answers the questions left open by Sears and Compco. ${ }^{180}$ Instead of the present system of common law protection for unpublished works and statutory copyright for published works, the Bill adopts a single system of federal statutory copyright from creation. Under section 302 , a work would obtain statutory protection from the time it is "created" or, as defined in section 101, "fixed in a copy or plonorecord for the first time." 187 The concept of publication would no longer be important as a dividing line between state and federal protection. This systern will undoubtedly promote national uniformity and avoid the present problems regarding the publication concept and the limited times provision of the Constitution. However, its preemption of state protection for phonograpli records which have been publicly distributed but not yet duplicated prior to the effective date of the statute ${ }^{188}$ may lead to substantial inequity.

The enactment of section 301 without further elucidation from Congress will raise a major question. Section 303 gives copyright protection to works created but not publisled or copyrighted before the effective date of the statute. ${ }^{189}$ Under the present law of a majority of states, publicly distributed sound recordings would be in this categorythey would be unpublished. ${ }^{190}$ The preemption provision of section 301 , however, may preclude the exercise of the state rules. ${ }^{101}$ Whether a federal definition of publication would be required for works created

185. 17 U.S.C. $\$ \S 1(\mathrm{e}), 101(\mathrm{e})$ (1964); see Henn, The Compulsory License,

General Revision of the Copyright Law 1 (Copyright Office Study No. 1 1957).

186. See notes 81-82 supra and accompanying text.

187. S. $543, \S 302$.

188. Id. $\$ \S 301(\mathrm{a}),(\mathrm{b})(2)$.

189. Id. $\$ 303$.

190. See note 89 supra.

191. On and after [the effective date of the Act] all rights in the nature of copyright in works that come within the subject matter [of the Act], whether created before or after that date and whether published or unpublished, are governed exclusively by this title. Thereafter, no person is entitled to copyright, literary property rights, or any equivalent legal or equitable right in any such work under the common law or statutes of any state.

S. $543, \S 301$ (emphasis added). 
before the effective date of the Act is left open. If a federal rule is required, the Act does not specify what it should be. If the new Act were to allow the pirating of all sound recordings released before its enactment, it would facilitate one of the greatest give-aways in the history of the law of literary property. The performers and record companies who made these records would stand to lose tremendous sums of money. ${ }^{192}$

Similarly, it is not clear whether sound recordings released prior to the effective date of the statute would continue to be performed publicly for profit without any payment beimg made under the performance right. These open issues will certamly lead to extensive litigation and Congress should make some provision for these recordings before it enacts the statute, if possible, in order to protect all parties concerned.

A major benefit of the Bill for composers and publishers, as well as for performers and record companies, is the elimination of the controversial "juke box exemption" from performance royalties. ${ }^{193}$ Under new section 116 all juke box operators are required to obtain a compulsory license for each machine they operate, affix a certificate to the machines, and pay a royalty fee each year for the use of sound recordings. ${ }^{194}$ Failure to perform these acts would subject the operator to criminal as well as civil liability. ${ }^{195}$

This provision has long been necessary in light of the law's failure to treat juke box operators the same as all others who play copyrighted music for profit. There is no reason why this select group should be able to profit from the recorded performances of musical artists without compensating them for the privilege. The juke box operators would thus be treated the same as radio and television broadcasters and all others who earn inconne from playing nuusical works. ${ }^{196}$

In its technical aspects the Revision Bill seems quite sound and is not dissimilar to the present Act. While the Bill does not specify who is to be the owner of the copyright in sound recordings, it seems that under section 201 the performer and record company will be treated as co-owners. ${ }^{197}$ As under the present law, they would thus be treated as tenants in common, with each having an independent right to use or li-

192. See 1967 Hearings 504.

193. Juke box operators are presently exempt from any performance royalties under 17 U.S.C. \& 1(e) (1964). See Mooney, The Jukebox Exemption, in 10 ASCAP CoPyRIGHT LAW SYMPOSIUM 194 (1959).

194. S. $543, \S \S 116(\mathrm{a})(2),(\mathrm{b})(1)(\mathrm{A})$.

195. Id. §§ $116(\mathrm{~b})(2), 501-06$.

196. Different royalty rates are, of course, established for each group of licenses, and the radio and television broadcasters are not subject to the criminal penalties of section 506. Id. § $114(\mathrm{c})(3)$.

197. H.R. REP. No. 83, 90th Cong., 1st Sess. $84-85$ (1967). 
cense the use of their work, subject to a duty of accounting to the other for any profits. ${ }^{198}$

It seems probable, however, that the record company will usually obtain the exclusive copyright. Virtually all phonograph records are presently made pursuant to contracts between manufacturers and recording artists. "Invariably such contracts contain an assignment by the performers of all rights in their recorded performances to the company in return for either a lump sum payment or, more usually, royalties."199 This practice may well continue, at least for the sake of convenience in making licensimg agreements and other arrangeinents under the new statute. ${ }^{200}$

The notice and deposit provisions of the Revision Bill are substantially the same as under the existing Act. Under section 403 (a) notice of copyright is required on all publicly distributed phonorecords. This notice must consist of three elements: the symbol $\mathbb{P}$, the year of first publication of the sound recording (distribution of phonorecords to the public), and the name of the owner of copyrights in the sound recording. ${ }^{201}$ This information must be placed on the surface in such a way as to give reasonable notice of the claim of copyright. ${ }^{202}$ Deposit of the sound recording-delivery of copies to the Copyright Office-is required under section 407(a)(2), but is not a condition of copyright protection. Registration is required, however, as a prerequisite to an action for infringement. ${ }^{203}$

The duration of the sound recording copyright will be basically the same as that of all other works under the Bill. ${ }^{204}$ It may vary, therefore, from a minimum of 50 years ${ }^{205}$ to 75 years, ${ }^{206}$ or perhaps even

198. Id.

199. Helfer, supra note 30 , at 156. For an example of such an agreement see id. at 156.

200. That the drafters thought the copyright would often not rest in the performer may be indicated by sections 114 (e)(3)(a) and 402(b)(3). Section 114(e)(3) (a) provides for division of the performance royalty between the copyright owners and the performers. S. $543, \S 114(\mathrm{e})(3)(\mathrm{a})$. Section $402(\mathrm{~b})(3)$, which is the notice provision, indicates that the producer of the sound recording shall be construed as the owner of the copyright if no other name appears in conjunction with the notice. Id. $\S 402(\mathrm{~b})(3)$.

201. Id. $\$ 402(\mathrm{~b})$.

202. Id. $\$ 402(\mathrm{c})$.

203. Id. $\S 411$. There is a special exception to this rule for "work[s] consisting of sounds, images, or both, the first fixation of which is made simultancously with its transmission." Id. $\$ 411$ (b); see Washingtonian Publishing Co. v. Pearson, 306 U.S. 30 (1939).

204. S. 543, § 302 .

205. Id. Section 302 provides that a copyright endures for the life of the author and, in addition, for a period of 50 years after his death. Thus, the copyright would remain valid for a minimum of 50 years even if the author died immediately after creating his work.

206. Id. $\S 302(\mathrm{c})$. This section places a limit of 75 years after the date of first publication on the time period. 
longer ${ }^{207}$ depending on how the copyright is taken.

\section{ConCLUSION}

Over the past 70 years performers and the record industry have been involved in a struggle to protect their works from commercial exploitation by others not willing to compensate them for their efforts. They have run into three major obstacles along the way-the failure of Congress to grant statutory protection to sound recordings im 1909, the decisions of Judge Learned Hand, and those of the United States Supreme Court in Sears and Compco. Each of these obstacles has been overcome only by the willingness of lower court judges to stretch the law in order to prevent the grossly unfair practice of record piracy.

The doctrines of common law copyright and unfair competition have been utilizcd on numerous occasions to prevent the unauthorized duplication of sound recordings. This has required a theoretical distortion of the concept of publication so as not to include the public sale and performance of phonograpl records, and a narrowing of the opinions of Justice Black in Sears and Compco. Such results are not satisfactory to performers, the public, or the law of literary and artistic property. The alternative, however, is no protection at all for these works. That would mean a disaster for the record industry in lost revenue, a blow to the public interest, and would result im a policy of encouraging a devious business practice.

The enactment of the Revision Bill will eliminate these problems and will end the currently perilous balancing act courts are forced to perform on the tightrope between fair practices and federal preemption. While presently there remain some relatively minor flaws in the Bill as it relates to sound recordings, the benefits from its enactment would be many. The copyright law of the United States would be brought into line with almost all of the other free nations of the world; uniformity throughout the country would be achieved; effect would be given to the full expanse of the copyright clause of the Constitution; a great deal of uncertainty as to the protection available to recorded performances would be eliminated; and, recognition would finally be given to an important artistic creation. Hopefully, enactment of this proposed statute will mark the final phase of the struggle to grant well deserved protection to the recording mdustry-artists and manufacturers alike.

John E. Mason, Jr.

207. Id. $\$ 302(\mathrm{~b})$. The time period would be extended if, for example, the last surviving member of a group holding a joint copyright survived more than 25 years after the work was created. 